\title{
Study of the mechanical properties of single- layer and multi-layer metallic coatings with protective-decorative applications
}

\author{
Sabina Cherneva ${ }^{1, *}$, Desislava Guergova ${ }^{2}$, Roumen Iankov ${ }^{1}$, and Dimitar Stoychev ${ }^{2}$ \\ ${ }^{1}$ Institute of Mechanics, Bulgarian Academy of Sciences, Acad. G. Bonchev St., B1.4, 1113 Sofia, \\ Bulgaria \\ ${ }^{2}$ Institute of Physical Chemistry, Bulgarian Academy of Sciences, Acad. G. Bonchev St., Bl.11, 1113 \\ Sofia, Bulgaria
}

\begin{abstract}
Single thin coating of matt nickel $\left(\mathrm{N}_{\text {imat }}\right)$, a mirror bright copper (Cubright), a mirror bright nickel (Nibright) and their combinations were electrochemically deposited on brass substrate with thickness $500 \mu \mathrm{m}$. The basic aim was electrodeposition of two-layer $\mathrm{Cu}_{\text {bright }} / \mathrm{Ni}_{\text {mat }}$ and $\mathrm{Nibright} / \mathrm{Cubright}$ systems, and three-layer Nibright $\mathrm{Cubrigh} / \mathrm{Nimat}$ system, which are among the most widely applied protective and decorative systems in light and medium operating conditions of corrosion. The thicknesses of the obtained films varied from $1 \mu \mathrm{m}$ to $3.25 \mu \mathrm{m}$. They were investigated via nanoindentation experiments, in order to characterize their basic physical and mechanical characteristics, related with their good adhesion and corrosion protective ability, as well as ensuring the integrity of the system "protective coating/substrate" to possible mechanical, dynamic and/or thermal stresses. As a result, load-displacement curves were obtained and indentation hardness and indentation modulus were calculated using the Oliver \& Pharr approximation method. The dependence of the indentation modulus and the indentation hardness on the depth of the indentation, surface morphology and structure of the obtained coatings, their texture and surface roughness were investigated too. The obtained results showed that the three-layer $\mathrm{Nibrigh/} / \mathrm{Cubright} / \mathrm{Ni} i_{\text {imat }} / \mathrm{CuZn} 37$ system has highest indentation modulus and indentation hardness, following by two-layer $\mathrm{Nibright} / \mathrm{Cubright}$ system and single layer coatings.
\end{abstract}

\section{Introduction}

It is considered that among the most reliable protective and decorative coatings of metal details (made of different types of steel or zinc, copper and aluminium alloys, which are exploited under different corrosion conditions) are electrodeposited coatings of copper, nickel and chromium [1], which can be combined into different double or triple systems. By properly combining the physico-chemical and physico-mechanical properties of these layers/systems, as well as the thickness and sequence of the arrangement/deposition, it can be substantially predetermined lifetime of the devices, as well as their functional operation.

*Corresponding author: sabina_cherneva@yahoo.com 
Along with the physico-chemical properties that determine the corrosion resistance of the protective coatings, the physico-mechanical properties of the deposited coatings/coating systems are of particular importance, as they have influence on their adhesion to the substrate and between them, their hardness and wear resistance, and etc.

In connection with this, it is important to have data about their properties, because in the case of electrochemically deposited protective metal layers, depending on the composition of working electrolytes and regimes in which are obtained, they differ too strongly from the physico-mechanical properties of metallurgically obtained metals (for which reference data are usually published).

In this connection the aim of present work was determination of indentation hardness $\left(\mathrm{H}_{\mathrm{IT}}\right)$ and indentation modulus $\left(\mathrm{E}_{\mathrm{IT}}\right)$ of single-layer thin films of mat nickel $\left(\mathrm{Ni}_{\text {mat }}\right)$, mirror bright copper $\left(\mathrm{Cu}_{\text {bright }}\right)$, mirror bright nickel $\left(\mathrm{Ni}_{\text {bright }}\right)$, as well as their combinations, designed to obtain the $\mathrm{Cu}_{\text {bright }} / \mathrm{Ni}_{\text {mat }}$ and $\mathrm{Ni}_{\text {bright }} / \mathrm{Cu}_{\text {bright }}$ double layer systems and the $\mathrm{Ni}_{\text {bright }} / \mathrm{Cu}_{\text {bright }} / \mathrm{Ni}_{\text {mat }}$ three-layer systems, electrochemically deposited on brass substrates $(\mathrm{CuZn37)}$, which are among the most widely used protective/decorative metal coatings/systems in light and medium operating/corrosion conditions.

\section{Experimental part}

The layers of electrochemically obtained fine crystalline copper, characterized by a mirror surface reflectance ( $96 \%$ vs. Silver mirror), were deposited on a 4 × $2 \mathrm{~cm}$ substrates, cut from brass $(\mathrm{CuZn} 37)$ sheet with a thickness of $0.5 \mathrm{~mm}$, which were carefully chemically degreased in organic solvent followed by etching and surface activation in aqueous solution of $\mathrm{HNO}_{3}(50 \mathrm{wt}$ \%) for $20 \mathrm{~s}$ at room temperature. The composition of the working electrolyte was: $\mathrm{CuSO}_{4} .5 \mathrm{H}_{2} \mathrm{O}-220 \mathrm{~g} / \mathrm{l} ; \mathrm{H}_{2} \mathrm{SO}_{4}-50 \mathrm{~g} / \mathrm{l} ; \mathrm{NaCl}-0,090 \mathrm{~g} / \mathrm{l}$; Brightening additive THB-6-II [2] - $5 \mathrm{ml} / 1$. Elliptic phosphorus-containing (0.07 wt.\%) copper anodes were used. The electrolyte temperature was $25^{\circ} \mathrm{C}$. The working standard two-electrode electrochemical cell in which the electrolysis was carried out was equipped with an airagitating device for the electrolyte, which was performed with specially purified compressed air, supplied at a rate of $13 \mathrm{~m}^{3} / \mathrm{m}^{2} / \mathrm{h}$. The cathode current density was 4.5 $\mathrm{A} / \mathrm{dm}^{2}$ and the thickness of the obtained bright copper layer was $\sim 2 \mu \mathrm{m}$.

The investigated mat nickel film was obtained electrochemically by means of cathode deposition on analogous substrates (with sizes $4 \times 2 \mathrm{~cm}$, cut from brass sheets with thickness $0.5 \mathrm{~mm}$ ), which were pre-treated chemically as described above. We used a working electrolyte with a following composition: $\mathrm{NiSO}_{4} .7 \mathrm{H}_{2} \mathrm{O}-270 \mathrm{~g} / \mathrm{l} ; \mathrm{NiCl}_{2} \cdot 6 \mathrm{H}_{2} \mathrm{O}-70$ $\mathrm{g} / \mathrm{l} ; \mathrm{H}_{3} \mathrm{BO}_{3}-40 \mathrm{~g} / \mathrm{l}$; and as soluble anodes - rolled de-passivated sheet nickel with a purity of $99.7 \%$. Electrochemical deposition was performed in a standard two-electrode electrochemical cell at a cathode current density of $2 \mathrm{~A} / \mathrm{dm}^{2}$ and air agitation of the electrolyte at a $\mathrm{pH} \sim 4.5$, temperature of $55^{\circ} \mathrm{C}$ and a deposition time of 2.5 minutes. The thickness of the obtained nickel coating was $\sim 1 \mu \mathrm{m}$.

The deposition of the bright nickel coating (necessary for the obtaining of the threelayer Nibrigth/Cubright/Nimat/CuZn37 system) was performed electrochemically by cathodic deposition on $4 \times 2 \mathrm{~cm}$ substrates, cut from brass (CuZn37) sheet with a thickness of $0.5 \mathrm{~mm}$, which were chemically pretreated as described above. We used a working electrolyte with a following composition: $\mathrm{NiSO}_{4} .7 \mathrm{H}_{2} \mathrm{O}-270 \mathrm{~g} / 1 ; \mathrm{NiCl}_{2} \cdot 6 \mathrm{H}_{2} \mathrm{O}-70 \mathrm{~g} / \mathrm{l} ; \mathrm{H}_{3} \mathrm{BO}_{3}$ - $40 \mathrm{~g} / \mathrm{l}$; saccharin - $1.1 \mathrm{~g} / \mathrm{l}$; butanediol - $0.3 \mathrm{~g} / \mathrm{l}$, and as soluble anodes - rolled depassivated sheet nickel with a purity of $99.7 \%$. Electrochemical deposition was performed in a standard two-electrode electrochemical cell at a $\mathrm{pH} \sim 4.5$, temperature of $55^{\circ} \mathrm{C}$, cathode current density of $5 \mathrm{~A} / \mathrm{dm}^{2}$, air agitation of the electrolyte and a deposition time of $1.7 \mathrm{~min}$.

The deposition of two-layer system - mat nickel (with thickness $\sim 1 \mu \mathrm{m}$ ), followed by bright copper (with thickness $\sim 2 \mu \mathrm{m}$ ) and three-layer system of: mat nickel (with thickness 
$\sim 1.4 \mu \mathrm{m}$ ), followed by bright copper film (with thickness $\sim 2 \mu \mathrm{m}$ ) and bright nickel film (with thickness $\sim 1,4 \mu \mathrm{m}$ ) on chemically degreased in organic solvent and etched in a suitable solution of $\mathrm{HNO}_{3}$ brass substrates, was performed sequentially according to the procedures described above for depositing of single-layer coatings (rinsing with deionised water was performed after each step).

Surface morphology and structure of the obtained coatings were investigated by JEM 200-CX scanning electron microscopy in secondary electron imaging regime (SEI), their texture by Philips X-ray diffractometer, the thickness of the layers was determined using Xray fluorescence analysis (FISHERSCOPE X-RAY XDVM), and their micro profile - with Perthen profilometer.

Table 1. Input parameters for nanoindentation experiments

\begin{tabular}{|c|c|c|}
\hline Parameter & Unit & Value \\
\hline Percent To Unload & $\%$ & 90 \\
\hline Surface Approach Velocity & $\mathrm{nm} / \mathrm{s}$ & 10 \\
\hline Delta X For Finding Surface & $\mu \mathrm{m}$ & -50 \\
\hline Delta Y For Finding Surface & $\mu \mathrm{m}$ & -50 \\
\hline Maximum Load & $\mathrm{gf}$ & 50 \\
\hline Load Rate Multiple For Unload Rate & {$[-]$} & 1 \\
\hline Number Of Times To Load & $\mathrm{nnteger}$ & 10 \\
\hline Allowable Drift Rate & $\mathrm{nm} / \mathrm{s}$ & 0.05 \\
\hline Approach Distance To Store & $\mathrm{nm}$ & 1000 \\
\hline Peak Hold Time & $\mathrm{s}$ & 10 \\
\hline Time To Load & $\mathrm{s}$ & 15 \\
\hline Surface Approach Distance & $\mathrm{nm}$ & 5000 \\
\hline Surface Approach Sensitivity & $\%$ & 40 \\
\hline Frame Stiffness Correction & $\mathrm{N} / \mathrm{m}$ & 0 \\
\hline Percent Unload In Stiffness Calculation & $\%$ & 50 \\
\hline Perform Drift Correction & $1 / 0$ & 1 \\
\hline Poisson's Ratio & {$[-]$} & 0.3 \\
\hline
\end{tabular}

Mechanical properties of the obtained films and brass substrate were investigated by nanoindentation experiments, using Nano Indenter G200 (Keysight Technologies, USA). The nanoindenter is equipped with a Berkovich three-sided diamond pyramid with centerline-to-face angle $65.3^{\circ}$ and a $20 \mathrm{~nm}$ radius at the tip of the indenter. The minimum allowed load is $10 \mathrm{mN}$, and the maximum load is $500 \mathrm{mN}$. Displacement recording resolution is $0.01 \mathrm{~nm}$ and the load recording resolution is $50 \mathrm{nN}$. The device is equipped with an optical microscope with 2 objectives with magnifications of $250 \mathrm{x}$ and 1000x. We made series of 25 or 12 indentations on each sample probe in order to have better statistics. We used an indentation method which prescribes series of 10 loading/unloading cycles in a single indentation experiment [3]. The maximum load was $50 \mathrm{gf}$ and we had $10 \mathrm{~s}$ peak hold time at maximum load for each loading-unloading cycle. Indentation hardness and modulus 
are determined using stiffness calculated from the slope of the load-displacement curve during each unloading cycle. As a result of nanoindentation experiments, loaddisplacement curves were obtained and two mechanical characteristics of substrate and investigated films - indentation hardness $\left(\mathrm{H}_{\mathrm{IT}}\right)$ and indentation modulus $\left(\mathrm{E}_{\mathrm{IT}}\right)$ were calculated using Oliver \& Pharr approximation method [4]. Dependence of indentation modulus and indentation hardness on depth of indentation was investigated as well. Basic input parameters, used in this indentation method are given in Table 1.

\section{Results and discussions}

In Figures 1 and 2 are presented SEM images-(obtained in BEI regime) and TEM images-of the structure of investigated copper layer. It can be seen from Figure 1 that it is extremely smooth (measured values for $R_{a}$ and $R_{z}$ are respectively $0.1 \mu \mathrm{m}$ and $0.14 \mu \mathrm{m}$ ) and it is made of isotropically arranged crystallites with cubic symmetry (Fig. 2), the dimensions of which are in the range $20-80 \mathrm{~nm}$. On the basis of the conducted X-ray investigations it was found that the coatings had a mixed texture, with a low degree of preferable orientation, in the directions [311] and [110]. Figure 3 shows a SEM micrograph (JEM 200$\mathrm{CX}$ in SEI mode) of the structure of the electrochemically deposited matt nickel, at a magnification 5,000x.

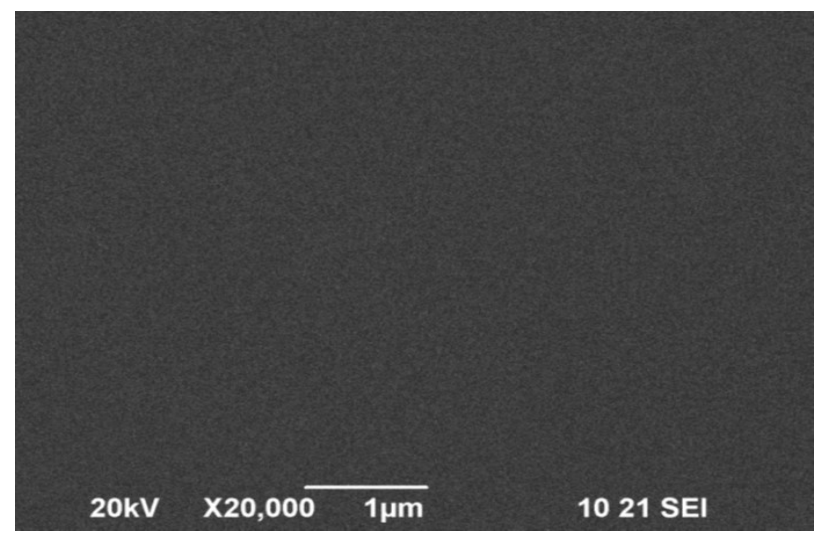

Fig.1 SEM micrograph of electrochemically deposited copper film $\mathrm{Cu}(1,8 \mu \mathrm{m}) / \mathrm{CuZn37}(\mathrm{X20} 000)$

It can be seen from obtained results, that the nickel layers are characterized by a relatively large crystalline homogeneous pyramidal structure made up of building aggregates with dimensions $\sim 50-500 \mathrm{~nm}$. The measured values for $\mathrm{Ra}$ and $\mathrm{Rz}$, which characterize the surface roughness of these layers, are respectively $0.1 \mu \mathrm{m}$ and $0.9 \mu \mathrm{m}$. Xray investigations showed that the coatings have a mixed texture in the directions [110] and [211].

Figure 4 shows a SEM image (JEM 200-CX in SEI mode) of the structure of the electrochemically deposited bright nickel coating at a magnification of $20,000 \times$. The nickel layers are extremely uniform, dense and finely dispersed, and are characterized by building blocks with sizes of 40-100 $\mathrm{nm}$. Coatings have a texture with a major axis of predominant orientation in the direction [211]. 


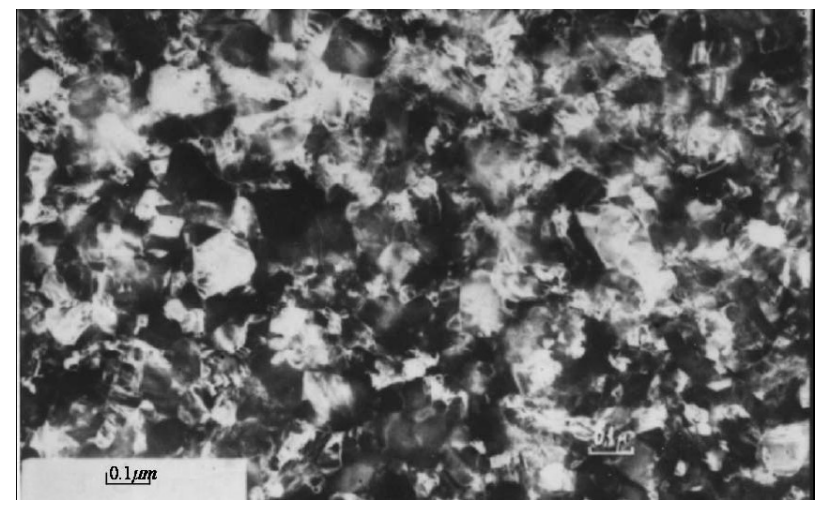

Fig.2 TEM micrograph of electrochemically deposited copper film $\mathrm{Cu}(1,8 \mu \mathrm{m}) / \mathrm{CuZn37}(\mathrm{X100} 000)$

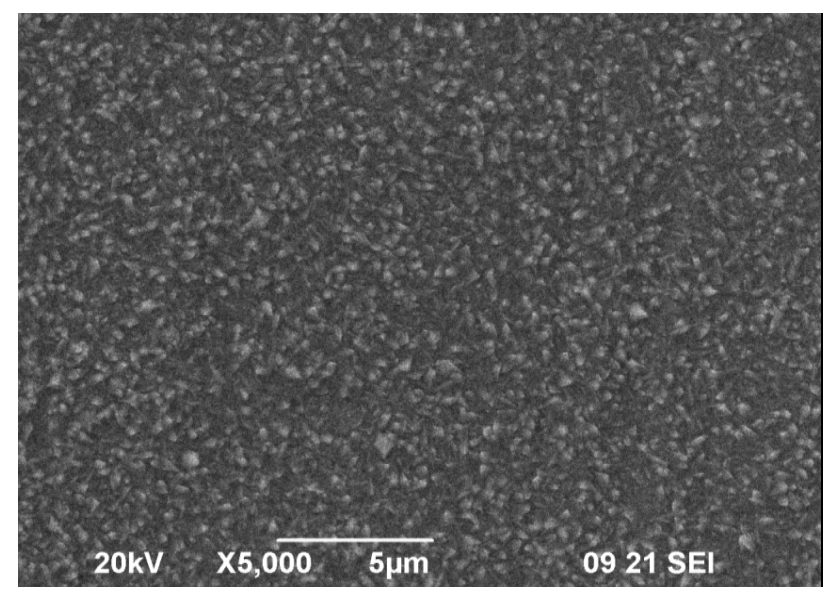

Fig.3 SEM micrograph of electrochemically deposited mat nickel film Ni $\mathrm{mat}_{\text {(1 }}(1 \mu \mathrm{m}) / \mathrm{CuZn} 37$ (X5 000)

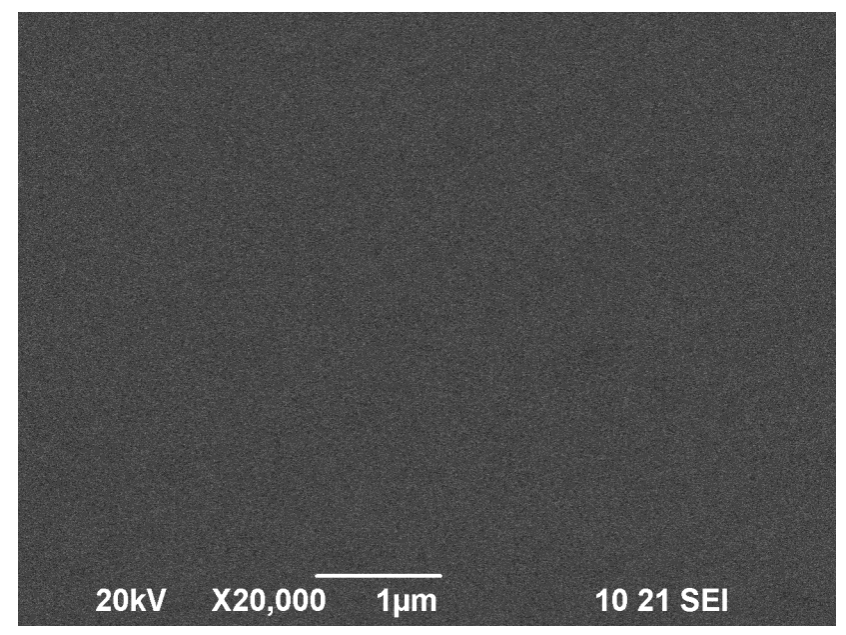

Fig.4 SEM micrograph of electrochemically deposited bright nickel film $N i_{b r i g h t}(1,8 \mu \mathrm{m}) / \mathrm{CuZn} 37$ (X20 000) 


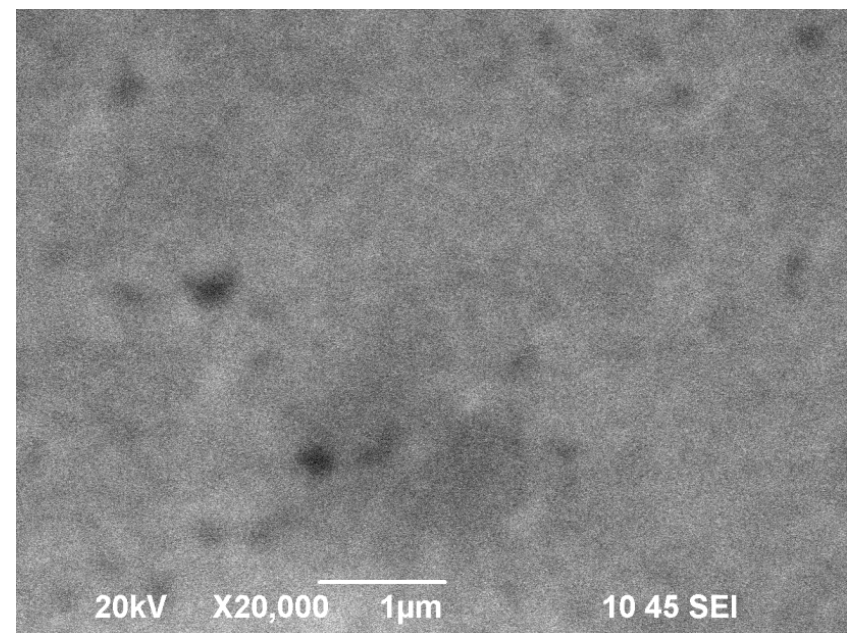

Fig. 5 SEM-photograph of the surface of the "upper" electrochemically deposited bright copper layer on the matt nickel layer, electrodeposited on a brass substrate $C u_{\text {bright }}(2,3 \mu \mathrm{m}) / \mathrm{Ni} i_{\text {mat }}(1,8 \mu \mathrm{m}) / \mathrm{CuZn} 37$ (X20 000)

Figure 5 shows an SEM image (JEM 200-CX in SEI mode) of the microstructure of the upper bright copper layer, deposited electrochemically on the matte nickel coating (20 $0000 \times$ ). Since the thickness of the copper layer is very small (in this case $2.3 \mu \mathrm{m}$ ), its leveling is not sufficient to flatten the microwells (dark spots) of the matt nickel coating (in this case the thickness is $1.1 \mu \mathrm{m}$ ). The surface morphology of the specimen, however, is dominated by the actual microstructure/habitus of the bright copper coating. The measured values for $R_{a}$ and $R_{z}$, that characterize the surface roughness due to the two layers are $0.1 \mu \mathrm{m}$ and $0.8 \mu \mathrm{m}$ respectively.

The deposition on a brass substrate of a three-layer coating of matt nickel (with thickness $1.4 \mu \mathrm{m}$ ), followed by a bright copper coating (with thickness $2 \mu \mathrm{m}$ ) and a bright nickel coating (with thickness $2 \mu \mathrm{m}$ ) was carried out consecutivelly (including intermediate distillated water washing operations and acid activation).

Figure 6 shows an electron microscopic photo (JEM 200-CX in SEI mode) of the microstructure of the upper bright nickel's layer surface, deposited electrochemically on the $\mathrm{Cu}_{\text {bright }}$ coating of the system $\mathrm{Cu}_{\text {bright }} / \mathrm{Ni}_{\text {mat }} / \mathrm{CuZn} 37(20,000 \times)$. The picture shows that the nickel coating is extremely smooth, dense and finely dispersed, which results both from the conditions of its production and the epitaxial effect of the extremely fine-grained and flattened intermediate mirror-bright copper coating. The measured values for $R_{a}$ and $R_{z}$, which characterize the surface roughness of the top bright nickel coating, are respectively $0.1 \mu \mathrm{m}$ and $1.1 \mu \mathrm{m}$. Undoubtedly, the $\mathrm{Cu}_{\text {bright }}$ and $\mathrm{Ni}_{\text {mat }}$ interlayers, as well as the brass substrate, have contributed to these values. For comparison, Fig. 7 shows the SEMmicrophotography on the surface of the brass $(\mathrm{CuZn37)}$ substrate, for which the measured $R_{a}$ and $R_{z}$ are respectively $0.2 \mu \mathrm{m}$ and $1 \mu \mathrm{m}$.

Data on thicknesses and micro-irregularities $\left(R_{a}\right.$ and $\left.R_{z}\right)$ of investigated individual layers, as well as for systems are given in Table 2.

As a result of nanoindentation experiments, load-displacement curves were obtained and two mechanical characteristics of substrate and investigated films - indentation hardness $\left(\mathrm{H}_{\mathrm{TT}}\right)$ and indentation modulus $\left(\mathrm{E}_{\mathrm{TT}}\right)$ - were calculated using Oliver \& Pharr approximation method $[5,6]$. The results we receive are objectively limited by the load / penetration potential of the used indenter(maximum load $=500 \mathrm{mN})$. That's why, the 
maximum load on the indenter did not allow a complete drilling of the three-layer coating to the substrate.

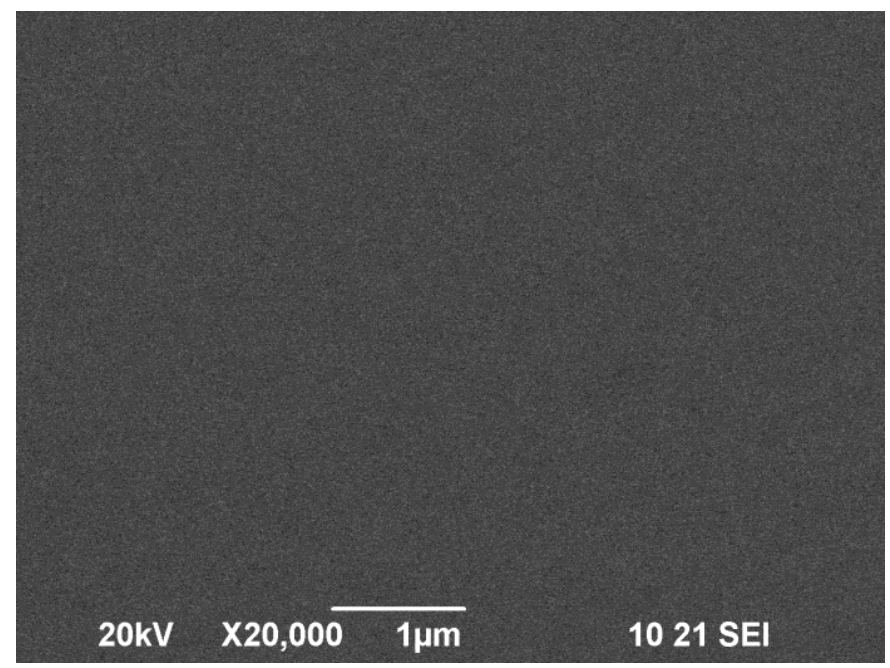

Fig.6 SEM image of the surface of the "upper" electrochemically deposited bright nickel layer of the "sandwich" system Nibright $(1,4 \mu m) / \mathrm{Cu}$ bright $(2 \mu m) / \mathrm{Ni}_{\text {mat }}(1,4 \mu m) / \mathrm{CuZn} 37$ (X20 000)

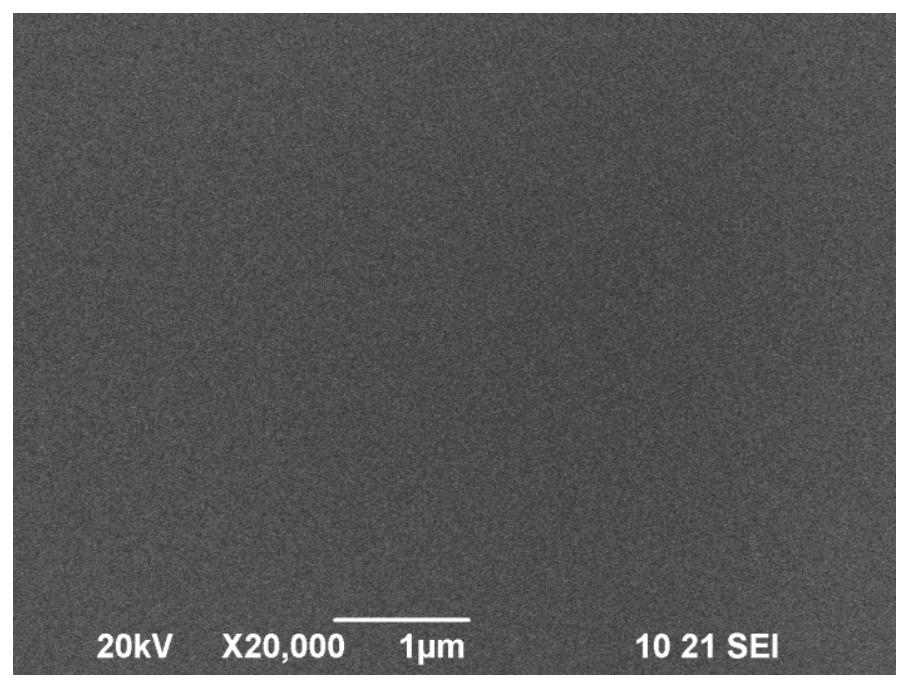

Fig.7 SEM photograph of the surface of the used CuZn37 substrates (X20 000) 
Table 2. Thickness and surface roughness of the investigated samples.

\begin{tabular}{|c|c|c|c|c|}
\hline No & Type of coatings & Thikness, $\mu \mathrm{m}$ & $\mathrm{R}_{\mathrm{a}}, \mu \mathrm{m}$ & $\mathrm{R}_{\mathrm{z}}, \mu \mathrm{m}$ \\
\hline 1 & $\mathrm{Cu}_{\text {bright }} / \mathrm{CuZn} 37$ & $1.78 / 500$ & 0.2 & 1.4 \\
\hline 2 & $\mathrm{Ni}_{\text {mat }} / \mathrm{CuZn} 37$ & $1.00 / 500$ & 0.1 & 0.9 \\
\hline 3 & $\mathrm{Cu}$ bright/ $/ \mathrm{Ni}_{\text {mat }} / \mathrm{CuZn} 37$ & $3.24 / 1.16 / 500$ & 0.1 & 0.8 \\
\hline 4 & $\mathrm{Ni}$ bright $/ \mathrm{Cu}_{\text {bright }} / \mathrm{Ni}_{\text {mat }} / \mathrm{CuZn} 37$ & $1.41 / 1.98 / 1.40 / 500$ & 0.1 & 1.1 \\
\hline 5 & $\begin{array}{l}\text { Degreasing and etching } \\
\text { treated substrate CuZn37 }\end{array}$ & 500 & 0.2 & 1.0 \\
\hline
\end{tabular}

The obtained results for indentation hardness and indentation modulus of investigated films are shown in Figs.8 and 9.

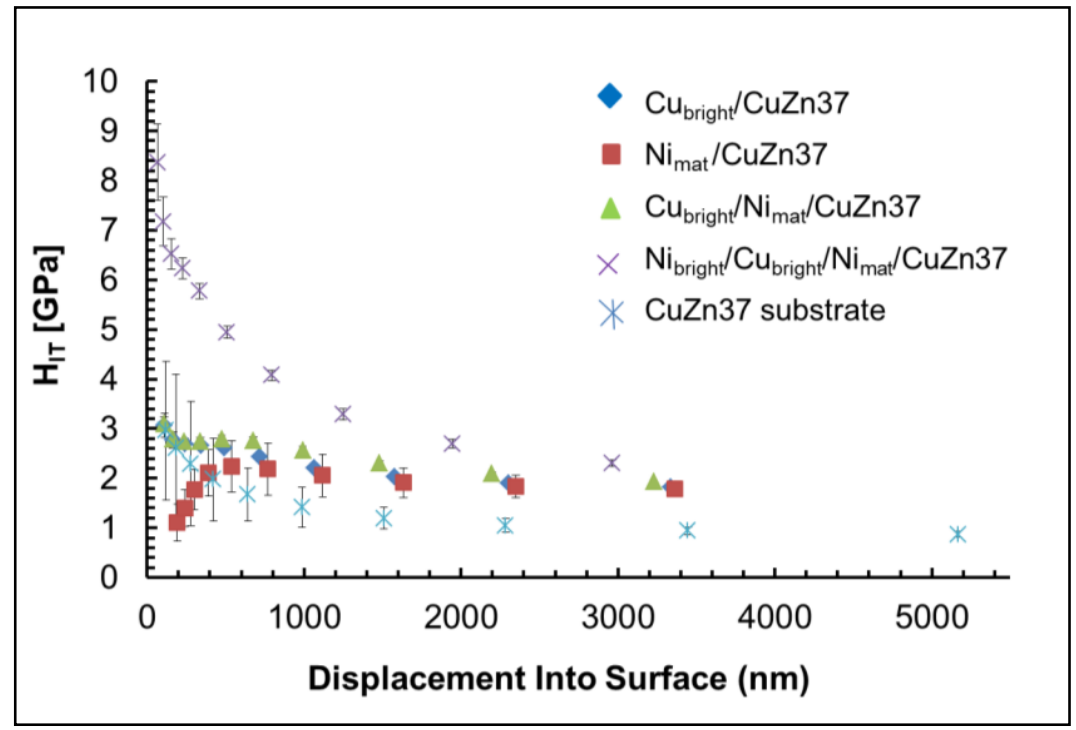

Fig.8. Indentation hardness of investigated multilayer films 


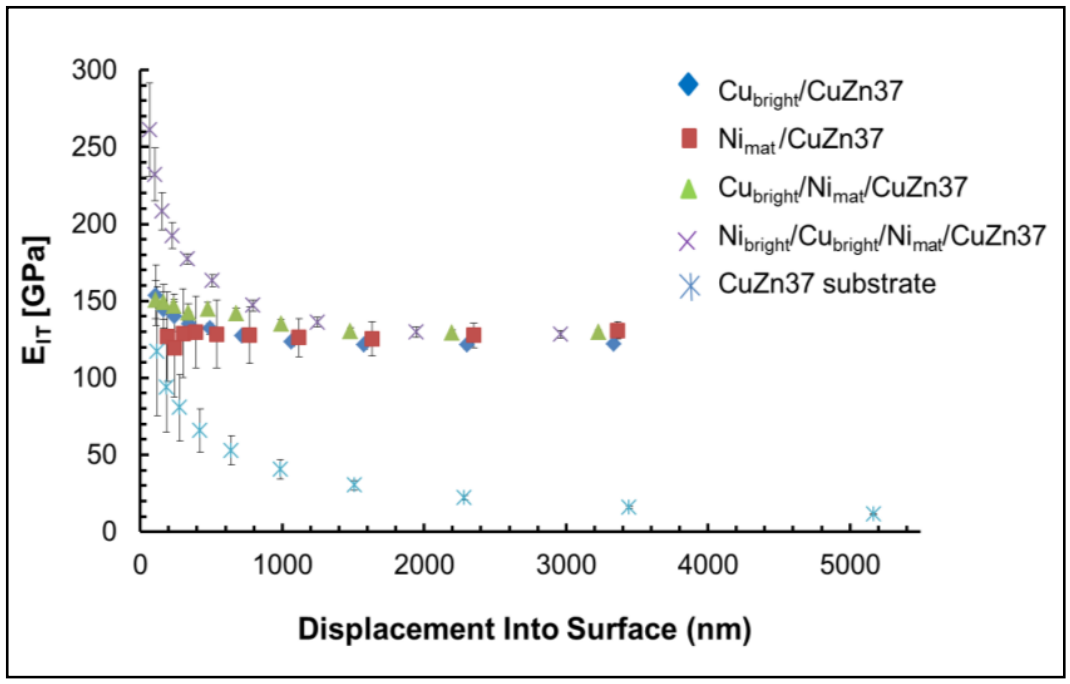

Fig.9 Indentation modulus of investigated multilayer films

It can be seen that the $\mathrm{Ni}$ bright $/ \mathrm{Cu}_{\text {bright }} / \mathrm{Ni}_{\text {mat }} / \mathrm{CuZn} 37$ three-layer coating has the highest indentation hardness and modulus, followed by the two-layer $\mathrm{Cu}_{\text {bright }} / \mathrm{Ni}_{\text {bright }}$ system and single layer coatings. The single $\mathrm{Cu}_{\text {bright }} / \mathrm{CuZn} 37$ layer has higher indentation hardness and indentation modulus than single $\mathrm{Ni}_{\text {mat }} / \mathrm{CuZn} 37$ layer, which is in good agreement with HallPetch relationship [7], because $\mathrm{Cu}_{\text {bright }} / \mathrm{CuZn} 37$ layer is more fine grained $(20-80 \mathrm{~nm})$ than $\mathrm{Ni}_{\text {mat }} / \mathrm{CuZn} 37$ layer $(50-500 \mathrm{~nm})$. With increasing depth of indentation, the indentation hardness and indentation modulus of both $\mathrm{Cu}_{\text {bright }} / \mathrm{CuZn} 37$ and $\mathrm{Ni}_{\text {mat }} / \mathrm{CuZn} 37$ layers becomes constant, but still higher than these of the substrate. This could be explained with pile-up of material around the indenter and indentation-induced densification of material under the indenter tip [8].

In triple layer $\mathrm{Ni}_{\text {bright }} / \mathrm{Cu}_{\text {bright }} / \mathrm{Ni}_{\text {mat }} / \mathrm{CuZn} 37$ coating with the inclusion of the third ( $\left.\mathrm{Ni}_{\text {bright }}\right)$ layer, indentation hardness and indentation modulus is drastically increased, which among the higher own hardness of brilliant nickel coating [1] may be associated with the presence of an additive effect, driven by the higher microhardness of the bilayer system (green curve) and its screening (reducing) of the influence of the soft brass substrate. In the same time, a decrease in indentation hardness and indentation modulus is recorded, with an increase in the penetration depth, which may be related to the influence of the softer $\mathrm{Cu}_{\text {bright }}$ layer. The obtained results are in good agreement with the obtained from other authors $[9,10]$.

\section{Conclusions}

In the present work we investigated by means of nanoindentation experiments mechanical properties of electrochemically deposited on brass substrate single-, two- and three-layer metal coatings, including nickel and copper layers. Surface morphology and structure of the obtained coatings, their texture and surface roughness were investigated too. The results show that the $\mathrm{Ni}_{\text {bright }} / \mathrm{Cu}_{\text {bright }} / \mathrm{Ni}_{\text {mat }} / \mathrm{CuZn} 37$ three-layer coating has the highest indentation hardness and modulus, followed by the two-layer $\mathrm{Cu}_{\text {bright }} / \mathrm{Ni}_{\text {bright }}$ system and single layer coatings. The conducted study indicates that in the assembly of electrochemically deposited multi-layer metal coatings, formation of protective and decorative systems with high corrosion-protective ability [1] is achieved, which are 
characterized by significantly better mechanical properties, compared to those of the individual layers. This fact is a guarantee of their better adhesion to the protected substrate in case of mechanical, thermal and corrosion attack.

Authors gratefully acknowledge the financial support of Bulgarian National Science Fund under Grant No. T02-22/12.12.2014.

\section{References}

1. Y. Matulis, Bright electrolytic coatings, ("Mintis" Publ. House, Vilnius, 1969).

2. D. Stoychev et al., Bulg. Pat. No No 43112.

3. M. Datcheva, S. Cherneva, D. Stoychev, R. Iankov, M. Stoycheva, Mater. Sci. Appl. 2, 1452 (2011).

4. W. Oliver, G. Pharr, J. Mater. Res. 19, 3 (2004).

5. J.C. Hay, A. Bolshakov, G.M. Pharr, J. Mater. Res. 14, 2296 (1999).

6. G.M. Pharr, A. Bolshakov, J. Mater. Res. 17, 2660 (2002).

7. W. Smith, J. Hashemi, Foundations of Materials Science and Engineering, $4^{\text {th }}$ ed., McGraw-Hill, New York, 2006.

8. S. Yoshida, H. Sawasato, T. Sugawara, Y. Miura, J. Matsuoka, J. Mater. Res. 25, 2203 (2010).

9. H.C. Barshilia, K.S. Rajam, Surf. Coat. Technol. 155, 195 (2002).

10. D. P. Cole, H. A. Bruck, Proceedings of the SEM Annual Conference, June 1-4, 2009 Albuquerque, New Mexico, USA. 